\title{
BIAS IN THE USE OF GOVERNMENTAL REGULATORY POWERS
}

\author{
Charles Abrams $\dagger$
}

$\mathbf{I}^{\mathbf{x}}$

N THE NINETEENTH CENTURY, most decisions in American economic life were made by businessmen. Government was in the nature of an impartial overseer, interfering with private enterprise only when the public conscience was shocked into action by a substantial violation of the rules. The occasions when the federal government became involved with the racial question were rare: an official might have to rule on how to classify a Negro in the Civil Service or how legally to provide a Jacksonville postoffice with separate toilets for Negroes and whites. The local official was guided by the "states rights" and "separate but equal" doctrines, and racial issues at the local level were resolved primarily through civil rights legislation.

Two distinct levels of ethics governed social conduct in Nineteenth Century America. The private entrepreneur functioned under the ethic of "caveat emptor," and "I am not my brother's keeper." The government's ethic was on a higher level, stemming from the nobler principles of fair dealings, due process, freedom of opportunity and equality. And though equality on the state level in the South was often satisfied by separate facilities, these had at least technically to be equal. Many northern state constitutions guaranteed civil and minority rights, while the federal Constitution checked unconscionable incursions upon the individual by either state or federal agencies.

Under the higher moral standards embodied in government constitutions and legislation, hotels, restaurants, theaters, ice-cream parlors, public conveyances, ${ }^{1}$ barber shops and public places were often forbidden by state law from discriminating; a federal law banned discrimination in the sale or lease of real estate; employers were forbidden to discriminate in carrying out public contracts and occasionally in private employment; unions were bound to the constitutional ethic when beneficiaries of public aid or power. ${ }^{2}$

In the operation of the private enterprise system where most day-to-day decisions were made, there were of course discriminations and prejudices, but they were the exceptions. The guiding principle of the system has been profit not caste, and as long as competition functions, goods flow, and power is diffused, the color of the money generally remains more decisive than the color of the

$\dagger$ Member of the New York Bar.

${ }^{1}$ State Anti-Discrimination and Anti-Bias Laws (American Jewish Congress, 1948); a federal law forbidding discrimination in public places was held unconstitutional in the Civil Rights Cases, 109 U.S. 3 (1883).

214 Stat. 27 (1866), 8 U.S.C.A. § 42 (1942); Steele v. Louisville \& Nashville Ry. Co., 323 U.S. 192 (1944); State Anti-Discrimination and Anti-Bias Laws, op. cit. supra note 1. 
customer. Talent not pigment influences the hiring of men and the purchase and sale of goods. When competition and the free market cease functioning, it becomes the duty of the government to intercede and break up the blocks. The free market system, checked by constitutions, courts and civil rights legislation, thus produced a highly favorable formula for social and economic opportunity.

The increasing complexities of industrialization challenged the formula on a number of occasions. Immigrants, unaccustomed to the new environment and often ignorant of the national language, aroused the antagonisms of the older settlers. The Irish, Germans and Scandinavians were despised with "especial virulence." The Bohemians, Czechs and Poles threw us into "paroxysms of fear." There were "ignorant Finns," "filthy Russians," and "Jews with the hungry look of the Shylock type." The antagonisms, however, were not longlasting. Each incoming group and their children ultimately became either socially assimilated or lived in tolerable consortium until distinguishing attitudes, fears and customs wore away.

It was not until the more recent expansion of government power and function that a well-defined trend toward the abuse of legislative, judicial and administrative processes became evident. It took form in perversions of the health and regulation powers, in the sinister use of public works undertakings, in administrative chicane, police action and inaction, misusage of judicial enforcement powers, and in the new federal programs launched under the spending power.

Now, however, the minority could no longer identify the encroachment upon its rights and challenge it directly. It had to go behind the law to find the motive, or prove that an official act in the name of law was actually a violation of constitutional safeguards.

\section{Health AND REgulatory Power}

One of the earliest uses of the expanding regulatory power had been to control buildings in the interests of health and safety. It was not long before this power was perverted to harass Chinese. A series of statutes to oppress them was first enacted on the West Coast. One San Francisco ordinance in the 1880's barred any person from maintaining a laundry without the consent of the Board of Supervisors except in buildings of brick and stone. Since the Chinese lived and worked in wooden buildings, many had to go out of business. The Supreme Court fortunately looked behind the innocent wording to discover the intent of the statute and declared it unconstitutional. ${ }^{3}$ In 1909 , a bill was introduced in California giving school trustees the "power to remove children of filthy or vicious habits or children suffering from contagious or infectious diseases, and also to establish separate schools for Indian children or for children of Mongolian or Japanese descent. This and similar legislation burgeoned into a cause célèbre when President Theodore Roosevelt asked that it be withdrawn in the interests of our relations with Japan."

Y Yick Wo v. Hopkins, 118 U.S. 356 (1886).

4 Stephenson, Race Distinctions in American Law 162 (1908). 
No sooner had interest in zoning developed than a local ordinance required all Chinese to move from any area occupied by them to another. This was struck down by a federal court as a violation of due process and equal protection. ${ }^{5} \mathrm{De}-$ spite these successes in the courts, however, a number of these devious bills found their way into the statute books. ${ }^{6}$

With the movement of Negroes toward cities, the use of zoning ordinances as a means of racial exclusion became more prominent. ${ }^{7}$ Such ordinances generally made it unlawful for both Negroes and Caucasians to occupy houses on any street in which the larger number of houses were occupied by members of the opposite race. They were validated in early rulings on the theory that equal protection was afforded the minority. In Buchanan v. Warley, ${ }^{8}$ however, such ordinances were declared unconstitutional.

While Buchanan ข. Warley discouraged racial zoning legislation, it did not end the use of the zoning weapon against minorities. Zoning ordinances were now designed to be constitutional on their face, but capable of lending themselves to discriminatory enforcement. Thus, an ordinance might be written so as to make it impractical in the first instance for a housing development to go ahead. Those who build for whites could then induce a modification of the ordinance pro forma. But the moment an unwelcome group threatens to move into the area, the officials could stand firm on the ordinance as written. In other cases, stricter zoning ordinances may be enacted just when a minority family is about to start building. In Miami, Florida, land which public officials thought would be used for Negro residences was summarily zoned for industrial uses only. The same technique was used outside of Philadelphia. In Pennsylvania, Los Angeles and Maryland, housing co-operatives were thwarted by zoning devices when local officials thought Negroes might be admitted. As long as the officials do not openly give reasons for their actions, recourse to the courts is utterly futile.

Zoning was officially recommended as a method for barring unwelcome races by the 1938 FHA "Underwriting Manual." Section 933 instructed the builder in how to keep out "adverse influences" and "unharmonious groups." The Manual stated: "One of the best artificial means of providing protection from adverse influences is through the medium of appropriate and well-drawn zoning ordinances."

Another device for checking minority movements is condemnation for public improvements. A Negro builder owning a site for a subdivision might first meet

${ }^{5}$ In re Lee Sing, 43 Fed. 359 (C. C. Cal., 1890).

- Murray, States' Laws on Race and Color 18 (1951).

${ }^{7}$ Hopkins v. City of Richmond, 117 Va. 692, 86 S.E. 139 (1915), rev'd, Irvine v. City of Clifton Forge, 97 S.E. 310 (1918); Hardin v. City of Atlanta, 147 Ga. 248, 93 S.E. 410 (1917), rev'd, Glover v. City of Atlanta, 148 Ga. 285, 96 S.E. 562 (1918); Harris v. City of Louisville, 165 Ky. 559, 177 S.W. 472 (1915).

245 U.S. 60 (1917). 
technical objections to his plans and then difficulty in getting his sewers or utility lines approved. If these devices fail to discourage him, the municipal authorities may discover that the land is needed for a public park. This device was employed in Detroit where the City Council condemned a Negro developer's land which he had bought for residential development. The site was neither suitable for a park nor was it ever intended for one.

In other cases sites abutting Negro developments have been acquired for railroad stations, incinerator dumps, urban redevelopment, public housing projects, roads and similar improvements. Such improvements sometimes tend to cut off the minority area from the rest of the city and stem the expansion of its living space. Where minority groups have already settled on the land, they may be summarily evicted. They are frequently forced to pay their own moving expenses. The owner is usually barred from raising any objection to the condemnation other than that the use is not public or that adequate compensation is not being paid. He may be barred from questioning the necessity for the condemnation, a determination which in some jurisdictions is conclusive upon the courts. The owner may thus have no recourse despite palpable misuse of the law.

Generally, the citizens' sensibilities may be assuaged by the knowledge that the minority owner has been "paid in full." Actually, however, the owner is fortunate if he gets two-thirds of his actual damage. For besides his outlays for attorneys' and appraisers' fees, moving costs and income taxes, he must find another house, and all too often he discovers that as a member of a minority he must pay more than market price. The demolition of his house and those of his neighbors, moreover, has shortened the supply of dwellings available to his group and made purchase of a house in that community all but impossible. Frequently, condemnation of his house leaves him no alternative but to abandon the community as well as his friends and his job.

In Los Angeles, Mexican-Americans were dispossessed under the condemnation power to make room for public works. In Miami, Florida, the City Council ordered a brand-new two million dollar housing project, into which Negroes had moved, condemned for public use. Unable to state the precise use, a list of uses was mentioned, including a park, public housing, a swimming pool, a stockade for city prisoners, and housing for teachers. Ultimately the use chosen was in connection with a sewage disposal system. ${ }^{9}$

In Detroit, Negro owners were told to move in the name of urban redevelopment. In Dearborn, the Mayor boasted of his success in keeping Negroes out of his city. In Chicago, eviction has been accomplished under the urban redevelopment program. In Washington, D.C., a Negro area was torn down to make room for a new Senate Office Building. It is often difficult to determine whether the selection of the minority area was deliberate or incidental, and in the case of the Senate Office Building might well have been unavoidable. But all too often the

- For details see writer's articles in N.Y. Post, Jan. 21 through Jan. 25, 1952. 
practice of choosing sites from which minorities are to be ousted is more than a coincidence. When the improvements happen to clear slums, they tend to receive local official approval. ${ }^{10}$

City planning has not escaped the tendency toward perversion. It offers a wide variety of word fronts such as "urban redevelopment," "zoning," "slum clearance," "greenbelt," "master plan," "beauty and amenity," etc. Most city plans and planners are well intentioned. But there have been an increasing number of oppressions. The dead-end street has sometimes become the method for keeping out the dark-skinned neighbors on the other side of the development; the boulevard may no longer be the terraced walk where the shuffing poor may observe the strutting rich, but is the new barricade against minority "invaders." Walls have been built in Detroit and Miami not for beauty and amenity but for exclusion of Negroes.

Two consultants on urban redevelopment for the government recommended methods for restraining "population movements."11 "It is extremely difficult," their report said, "almost impossible to keep up people's morale in a threatened neighborhood unless they feel contained. Only real boundaries between them and the danger of infiltration will allow them to feel effective in combating the danger.... There are, however, many possibilities for creating artificial boundaries. ... The complete closing of streets, and the creation of small parks can also for a time delay pressure even from great population movements."

\section{ADMINISTRATIVE Devices}

Administrative chicane is highly difficult to detect and contest. With the expansion of government, there have been numerous administrative agencies set up with wide areas of discretion. These include among others, city departments of various kinds, planning commissions, zoning commissions, urban redevelopment and housing authorities, boards of standards and appeals and licensing commissions. They are not prone to make a record of their discriminatory policies or give the minority the evidence on which their oppressions can be tested.

Filing of building violations is one method for keeping minorities in tow. The owner may be told his house is unsanitary or unsafe, or a list of violations may be filed against his building, compliance with which would cost a ransom. Contesting an inspector's determination of what is safe or unsafe, sanitary or unsanitary, complied with or uncomplied with, is often impossible.

Raising the assessed valuation is another device. A substantial tax increase may destroy all or a large part of the equity value. Since value of a building is no more than an opinion of a local assessor, the action is difficult to attack, and

${ }^{10}$ Slum clearance is of course commendable when the evicted occupants can be relocated. Too often the occupants are summarily evicted with no attention paid to their relocation needs. The social damage is then far greater than if the buildings had been left standing and the slumdwellers undisturbed.

11 Report U.D. 3, Preliminary Report on Conservation of Middle-Aged Neighborhoods and Properties, Appendices at 29 (NHA, Urban Redevelopment Div., 1944). 
recourse to the courts is cumbrous. Even if the victim should win in the courts, he finds the cost of the fight a heavy burden. Outside Atlantic City, a wealthy Negro woman purchased a hotel which she had intended to rent to Negroes. She soon learned that a prohibitive tax assessment would be registered if she were to carry out her plan. She then offered her property to whites.

Another device employed to discourage private projects for minorities is the practice of disapproving plans or specifications. The refusal by the municipal authority is on technical grounds and it is often impossible to discover the real motive or get at the facts on which to raise the issue in the courts.

A stratagem combining legislative and administrative power was an ordinance adopted by the Board of Commissioners in Montgomery County, Pennsylvania. ${ }^{12}$ Its purpose was to check a subdivision undertaken by a co-operative which might admit a few Negroes. The ordinance provided that no building permit could be issued for the construction of a building in a subdivision until the plan of the subdivision had first been approved and a bond filed insuring the completion of the streets and other public improvements. After various technical obstructions were interposed, the co-operative was informed by the Township that the bond would be in the amount of $\$ 165,000$. Thereafter the Commissioners amended the zoning ordinance by providing for building regulations which made it impossible for the co-operative to build the type of houses it had planned and to secure the bond guaranteeing the street improvements. After spending some $\$ 21,000$ in plans and salaries and being hampered and delayed at every turn, the co-operative abandoned the project.

Another method for discouraging an intruding minority group is to thwart or delay the dedication of streets and the laying of sewer and water lines or to refuse arbitrarily to interpret a building requirement. If the courageous venturers persist, there is always a legal way of chastising them such as failing to supply city services or putting the city dump in the area.

The civil rights lawyer today is no longer afforded the luxury of the clear test or the admitted facts. Each case requires money, labor and patience to dig out evidence, and in the end victory may establish only that the particular administrative act was unreasonable and thus have only local significance.

\section{Police Action and Inaction}

The police force is potentially the most dangerous instrumentality for checking minority movements. Since police commissioners are locally appointed and policemen are local residents, they feel they must cotton to majority opinion to retain their jobs.

Police action can break up a mob or encourage it to run riot. An officer can guard or look the other way. He can seek out the culprit or lose sight of him. A local procurer may be allowed to operate on the main street, but a Negro war veteran might not be permitted to settle within two miles.

${ }^{12}$ American Veterans Housing Co-operative, Inc. v. Zoning Board, 69 Pa. D. \& C. 449 (1949); see also Hunt, The Battle of Abington Township, 9 Commentary 234 (March, 1950). 
There are enough empty lots in the City of Chicago for 500,000 houses and enough in Cook County for several million. But a Negro who tries to establish himself in a white area meets obstacles that range from open assault to race riots. In most cases, the Negro home builder is frustrated before violence becomes necessary. He may find it impossible to finance; contractors may refuse to build for him; FHA may be cool to his effort; and land will be difficult to secure. The contractor or lender who helps him may find himself the object of disesteem or reprisal.

A Negro savings and loan association in Chicago is prepared to lend money for the construction of Negro housing in white areas. But the big obstacle to building in alien territory is arson. To borrow the money from the Negro savings and loan association or any other source, fire insurance must be obtained during the various stages of construction. This is impossible on land outside established Negro zones. Fire insurance companies have seen too many of such ventures go up in smoke to gamble on the risk. In 1946, Chicago witnessed thirty-five such cases of arson, and since then hundreds of "incidents," i.e., bombings, fires or organized assaults. Between October and December 1951, a wave of dynamitings against Negroes, Jews and Catholics struck the Miami area in Florida. The burning of a Negro veteran's home in another southern city recently got nationwide publicity when a newspaper undertook a campaign to raise enough funds to compensate him for his loss. This is hopeful, but unique.

Arson is not the only menace; police indiligence is another. In one case a Chicago house owner threatened by a mob for challenging the color line was followed by police to his job, ostensibly to protect him against assault. But the police looked the other way when their protégé received an occasional whacking from a hit-and-run assailant. In most of the Cook County riots from 1945 to July 1951, police action could have checked the rock throwing and rioting had the police been disposed to do so. Police at strategic points in relation to riots can frustrate the throwing of rocks or flares. The arresting of offenders can not only publicize official cooperation, but discourage rioting.

This the police can do if they wish. Thanks to a few leaders in the area, like the late Thomas H. Wright, of Chicago's Commission on Human Relations, some headway has been made in recent years in getting police and public offcials to cooperate. George Schermer of the Mayor's Interracial Committee in Detroit is another official who has made police more sensitive to their obligations. There are others. But their successes have been far from complete. The political pressures against race relations officials at the city level are great and an unsympathetic mayor can make their job untenable.

\section{REstrictive COVENANTS}

Judicial enforcement of restrictive covenants is another device which has been used to check minority expansion. The covenant was used first against Chinese and enjoined by federal decision. ${ }^{13}$ State courts, however, upheld such

18 Gandolfo v. Hartman, 49 Fed. 181 (C. C. Cal., 1892). 
covenants and enforced them. Their use soon spread with epidemic speed from coast to coast. The groups proscribed were not only Chinese and Negroes, but Mexicans, Armenians, Japanese, Jews, Persians, Syrians, Filipinos, American Indians, and "other non-Caucasians."

The restrictive covenant issue came before the United States Supreme Court in 1929 and, though the Court parried the issue, it supplied enough dicta to suggest its approval of racial covenant practices. ${ }^{14}$

Up to 1910, Negroes had been scattered in various parts of cities and tensions were few. More than seven million houses went up in the 1920's, virtually all of them for whites. Had the building boom included open-land developments for Negroes, the tendency toward the crowded slum ghetto might have been avoided and suburban development for Negroes launched. Between the time of the Corrigan decision and the ultimate review of the issue by the Supreme Court in 1948, the Negro migration to the North accelerated and the pattern of Negro ghettos in the central city became firmly rooted in the American scene. Suburban development was almost wholly barred to them. In this sense, the failure of the Supreme Court to strike down the covenant in 1929 may be said to have contributed heavily to the pattern of racial segregation and suburban exclusion which has heightened racial tensions in American communities.

Though judicial enforcement of the covenants was finally enjoined, ${ }^{15}$ the covenant itself was not invalidated and its use still persists. In Washington, D.C., for example, the two candidates for the Vice-Presidency in the 1952 campaign (as well as some other high officials) executed agreements to abide by covenants which barred "any person or persons of negro blood or extraction or ... any person of the Semitic Race, blood or origin, which racial description shall be deemed to include Armenians, Jews, Hebrews, Persians, and Syrians. ..." The sanction of such covenants sets an example, lends a morality to its use and contributes to the lasting stratification of racial patterns in the nation's capital and elsewhere. ${ }^{16}$

\section{The Federax Housivg Admenistration}

From the inception of the Federal Housing Administration, discrimination practices have prevailed among its officials. Its "Underwriting Manual" provided that properties should continue "to be occupied by the same social and racial classes." One of its responsibilities was considered to be the "prevention of infiltration." It even exhorted the use of a model covenant providing that "no persons of any race other than (race to be inserted) shall use or occupy

14 Corrigan v. Buckley, 271 U.S. 323 (1926).

${ }^{15}$ Shelley v. Kraemer, 334 U.S. 1 (1948); Hurd v. Hodge, 334 U.S. 24 (1948).

${ }^{16}$ Despite the Supreme Court decision outlawing its enforcement, there have been at least nine devices for evasion of the covenant. These were first described in my article in the N.Y. Post of May 14, 1948, and later, in The Segregation Threat in Housing, 7 Commentary 123 (Feb., 1949). 
any building or any lot, except that this covenant shall not prevent occupancy by domestic servants of a different race domiciled with an owner or tenant."

The manual was studded with instructions of a similar character. ${ }^{17}$ After a long and stubborn insistence upon maintaining its segregation policy, which continued even after the Supreme Court decision had outlawed enforcement of racial restrictive covenants, ${ }^{18}$ FHA yielded to the pressures of the NAACP and other organizations and excised the objectionable sections from the Manual. But the damage had been done.

FHA practices are not always confined to its written word. FHA officials in the field exercise potent influence upon the racial composition of neighborhoods. Trained in the gospel that Negroes inevitably destroy real estate values, they frequently recommend disapproval of sites which Negroes have chosen. On exceptional occasions such sites will be approved, but usually where the neighborhood is accepted as a Negro neighborhood and does not abut a potential white development. Since FHA is the leading influence in home building, FHA practices have been cementing racial segregation in American neighborhoods. Despite FHA's vast power, no adequate mechanism has been set up to test its improvisations, identify its biases or expose its surreptitious violations of constitutional rights to judicial scrutiny.

\section{URBAN REDEVELOPMENT}

Urban redevelopment is an outgrowth of the slum clearance movement. It won popularity toward the end of World War II as a two-pronged device to prime the country out of the anticipated postwar slump and remove urban blight from the American landscape.

In 1949, Congress passed a "comprehensive housing bill" containing a formula under which land ripe for redevelopment could be acquired by local agencies and the land cost written down to a price that would make redevelopment profitable. While public housing authorities were permitted to benefit from the write down, the program was designed primarily to aid private developers, who were given first call on the land to be acquired.

The Act listed four types of projects eligible for federal aid: 1) Slum or deteriorated areas; 2) A deteriorated area to be developed for predominantly residential uses; 3) Land "predominantly open" but obsoletely platted or in diverse ownership; and 4) "Open land necessary for sound community growth" to be developed for residential use. The Act clearly intended the uses to be in the alternative. Despite this, however, the Administrator of the Housing and Home Finance Agency ruled that open land may be used only as part of a slum project. He claimed that a letter he sent to Senator Paul H. Douglas during the debate in the Senate "legally and morally obligated [me] to administer the open

17 Underwriting Manual $\S \S 310,315,330$ (1935); ibid., $\S \S 210,229,233,249,284$ (1936); ibid., $\$ 937$ (1938).

${ }^{18}$ Shelley v. Kraemer, 334 U.S. 1 (1948). 
land provisions in accordance with the requirements stated above."19 Open-land projects will be permitted only where "necessitated by the displacement of families through slum clearance." The main emphasis in the program was now on slum projects which displaced minority families, while virtually no openland projects were actually approved either independently or as part of such slum projects.

In July 1952, the writer received from the Housing and Home Finance Agency a telling summary of the urban redevelopment projects approved as of June 23, 1952. It showed the following:

1) Seventy urban redevelopment projects were approved. Every one of them proposed to displace families. The total number of families to be displaced was 45,450 .

2) Not a single project approved was to be built on open land as authorized by the statute, and only five were "predominantly open."

3) Of the 45,450 families to be displaced, all but 13,650 were listed as "nonwhite" and a goodly proportion of the whites appeared to be members of other minority groups for whom housing was not easily available (Puerto Ricans in New York, Mexicans in the West, and others).

Though only the public housing program could provide accommodations for the displaced families, only 1,778 families were to be provided with such housing. (One thousand of these were in Norfolk, Virginia, which has always been held out as a model project. Yet even here, of 2,930 families all but 15 were nonwhite.)

From the above tabulation it appears clear that urban redevelopment, begun as a social reform was, like many other social reforms, deffected from its originally creditable aim and turned into another instrument for harrying minorities. ${ }^{20}$

19 Quoted from letter of Housing and Home Finance Agency Administrator Raymond M. Foley to Lee F. Johnson, Executive Vice-President, National Housing Conference (Feb. 8, 1952).

${ }^{20}$ The Administrator's ruling demonstrates how administrative interpretation may sometime even nullify a statute. The law seems established that when the provisions of a statute are clear, a letter such as the Administrator sent to Senator Douglas is not relevant as an indication of legislative intent.

In Ex Parte Collett, 337 U.S. 55, 61 (1949), noting that the petitioner's argument proceeded "not from one side or the other of the literal boundaries of [the Section] but from its legislative history," the Supreme Court said tersely, "The short answer is that there is no need to refer to the legislative history where the statutory language is clear." Legislative history and other "extrinsic aids to construction" may be turned to only " "to solve, but not to create an ambiguity.... If the language be clear ... there is nothing to construe." "United States v. Shreveport Grain \& Elevator Co., 287 U.S. 77, 83 (1932).

The logic of the ruling is plain. The Constitution, in requiring three readings of an act in each house intended to insure that the listening legislators knew what they were voting on. Thereafter lawyers and their clients have a right to rely on the clear provisions of a statute without having to resolve the mental permutations of a Congressman who may have been instrumental in its passage. No lawyer carries a sheaf of Congressional Records of the last fifty years to enlighten him on whether a simple sentence means what it says, and no lawyer should be obliged to do so.

When a bill is introduced and its meaning is clear, the rank and fle who have read it and 
The abuse of the urban redevelopment power can be far more mischievous than the misuse of the zoning power or enforcement of racial covenants. Covenants are private agreements while urban redevelopment is publicly subsidized and backed by official power. Both racial zoning ordinances and covenants bar minorities from designated sites, but urban redevelopment ousts them from housing they already have. The need for careful checks upon official power is particularly emphasized by the fact that the proportion of overcrowding for nonwhites is now four times as great as for whites, and the proportion of substandard housing occupied by nonwhites is six times as great.21

The listing of these trespasses upon minority rights is not meant to obscure the gains made in recent years. However makeshift the houses, the fact is that the Negro has been establishing himself in the cities, and while tensions exist, they can be relaxed through planning and sensible housing programs. The public housing projects which have succeeded in integrating Negroes and whites in new neighborhoods are excellent examples of what can be done.

But there are dangers in indifference. Sanctions of racial exclusion practices are lending a morality to anti-Negro discrimination and segregation in northern sections where it had never been known before. Vast pools of government capital and credit are enabling the construction of huge racially-segregated areas, cementing segregation in schools, employment and public facilities. Emphasis upon "local autonomy" is vesting in local officials powers of exclusion which may markedly check social fluidity. Overcrowding, the worst aspect of slum life, is being intensifed, bringing in its wake disease, delinquency, despair, and deterioration of the family structure.

To counteract the trend toward abuse of political instruments of government it must be recognized that the courts can no longer be looked to for the sole or even the main source of protection. New approaches and new devices are needed: citizens and citizen organizations must be alerted to the corroding influences of official mischief generated by racial bias. The National Committee against Discrimination in Housing, the NAACP and similar organizations can play a vital part. But expansion of citizen organizations and citizen responsibility at the local level is needed as well. Greater federal leadership in protecting civil rights is also needed. The Republican Party Platform in 1952, which made

urged its enactment, the people affected by it, the press that supported it, and the President who signed it, all have a right to rely on its plain meaning. Nor may we assume that every Senator, and thereafter every Representative in the House, read the Record and knew about the Administrator's letter, or if they did know it, intended to substitute its content for the plain words of the statute. If this were so we should be substituting the law of the letter for the letter of the law.

${ }^{21}$ On January 15, 1953, after continued pressure by the writer and others, the Housing and Home Finance Agency issued a regulation attempting in general terms to check the continued displacement of minorities by urban redevelopment. As in previous experiences, however, the effectiveness of the regulation will, of course, ultimately be determined by the good faith of the Administration rather than by the letter of the regulation. 
federal responsibility "supplemental" to states' rights in this area, was an unfortunate misconception of federal and state function. Federal responsibility to secure civil rights is and has been primary and should remain so.

The duties and personnel of the Civil Rights Division of the Department of Justice should be expanded. The Division should be headed by an outstanding lawyer and might be reinforced by an advisory committee of leading citizens who can add to its prestige and protect its functions against political manipulations.

Proper forums and procedures should be set up for exposing administrative infractions of minority rights. Where complaints of officialized oppressions have been made, public officials might be required to answer under oath at preliminary hearings so that proper challenge of constitutional violations may be made in courts. A board should be set up by the President to facilitate the airing of anti-racial practices by such federal agencies as the FHA and other agencies in which anti-racial practices have been common. State boards might be set up to check abuse on the local level.

Manifestly these recommendations are not complete, nor are protecting agencies themselves free from corruption. But civic leadership and the assumption of federal responsibility can all help in shoring up the structure of morality now being shaken at the official level by assaults upon minority rights. 